\title{
SOME MODERN METHODS OF SEWAGE TREATMENT.
}

\author{
BY D. EDGAR FLINN, D.P.H., F.R.C.S., M.R.C.P.; \\ Examiner in State Medicine, Royal Colleges of Physicians' and Surgeons. \\ Conjoint Board ; \\ Formerly Medical Officer of Health, East Staffordshire.
}

[Read in the Section of State Medicine, May 6, 1892.]

Dr. Alfred Carpenter has truly said that- "It is the object of the sanitarian to bring about conditions which diminish the frequency of early death, which assist to remove bodily pain from the list of human grievances, and to pave the way for that time when every person born into the world will enjoy his birthright, without having it curtailed by the acts of other people."

THE object I had in view in the drafting of this paper was to draw the attention of this Section to the benefits derivable from the most recent methods of sewage disposal. "The sewage problem," as it has been aptly termed, has passed through many stages during the past twenty years or more, but it is only within the last few years that scientific knowledge has sufficiently advanced to bring this vexed question within the possibility of a final and successful solution. Sanitarians have devoted themselves assiduously to grapple with the difficulties that beset their way in the disposal of the sewage of cities and towns, and if they had not, to a great extent, surmounted these difficulties, the condition of the large centres of population would long ere this have become intolerable. Further, in regard to the progress that has been made in sanitary science, the reign of Queen Victoria will ever stand prominently forth as a most important epoch, as at the time of her accession the sanitary condition of the people was as bad as bad could be. 


\section{Some Modern Methodss of Sewage Treatment.}

There has been a rapid advance in the question of sewage treatment during the last ten years, and I opine that we have not yet come to a finality in this regard. The enforcement of the provisions of the Rivers Pollution Prevention Act of 1876 has become much more stringent, and effluents must attain a much higher standard of purity than heretofore. Previously to $\mathbf{1 8 7 6}$ sewage matter and refuse from manufactories were discharged into rivers and streams, and the result was a wholesale pollution of the watercourses throughout the country. For some time after the Act mentioned above was passed, there was a great difficulty in the enforcement of its provisions, and it is only in very recent years that the benefits intended by its enactment have commenced to take effect. The new methods of sewage treatment have, no doubt, helped very much to this end, and the authorities have become much more alive to the necessity of preserving the waterways pure and wholesome. The alacrity with which sanitary reformers, as recently as twenty years ago, were anxious to get rid of refuse by pouring it into the nearest watercourse, completely blinded them to the fact that they were only temporarily relieving themselves of an evil that must, sooner or later, have its pernicious results elsewhere.

Three principal methods are recognised and are in use for the purification and disposal of sewage-viz., precipitation, filtration, and irrigation. The precipitation process is carried out by means of various reagents-the principal object in view being the purification of the sewage-lime, either alone or in conjunction with other chemicals, being most frequently used. The process of precipitation by lime has been pronounced, by the Rivers' Pollution Commissioners, "to be a conspicuous failure ;" indeed, practically, the same may be said of the majority of the other methods employed in the precipitation of sewage, notably the lime 
and sulphate of alumina process; the A. B. C. (alum, blood and clay) process; the lime and chloride of iron process, \&c. The defined position of precipitation of sewage may be summed up in the words of Dr. Dupré, F.R.S., a well-known authority on sewage purification. He says: "As regards processes of precipitation I will merely remark that inasmuch as no proportion of chemicals which can practically be employed will do much more than clarify the sewage, the proportion of chemicals employed should be kept as low as is consistent with the object to be attained-namely, clarification; and that, more particularly, the use of large quantities of lime should be avoided." In the more modern process, known as "the ferozone and polarite process," which will be subsequently referred to, the introduction of the precipitating material ferozone is followed by filtration of the effluent through a filter containing polarite. The advantage of having a precipitant immediately followed by a filtering medium is obvious.

The filtration system of sewage purification is divided into simple filtration and intermittent downward filtration. In the former process the sewage is merely strained or screened, but the effluent is not purified. In the latter process, that of downward filtration, the Rivers' Pollution Commissioners reported that no system was attended with better results than the filtration of sewage through a considerable depth of soil. According to the Report of the Commissioners this process of sewage purification "was essentially one of oxidation, the organic matter being converted into carbonic acid, water, and nitric acid; hence the necessity for the continual aëration of the filtering medium which was secured by intermittent downward filtration." The requisite filtering area required to carry out this process of purification, as estimated by the Commissioners, is one acre, drained to a depth of six feet for every 3,300 of the population. 
The process of irrigation on sewage farms is the one attended with most beneficial results, as it not only secures a purified effluent, but, in most instances, becomes a source of profit, and utilises the value of the sewage for the benefit of the crops grown on the land; but to insure success the surface must be irrigated on the intermittent system to allow of sufficient aëration of the soil, and no doubt the best purifying results will be obtained by a combination of both methods-viz., irrigation and intermittent downward filtration. This system is in operation at Birmingham, Wolverhampton, Leamington, Reading, Doncaster, Croydon, Nottingham, Warwick, and other smaller towns.

The comparative merits of the systems of purification of sewage are given by the Rivers' Pollution Commissioners, as follows :-

AVERAGE RESULTS.

\begin{tabular}{lccc} 
& $\begin{array}{c}\text { Percentage of Dissolved Organic } \\
\text { Yollution removed }\end{array}$ & $\begin{array}{c}\text { Percentage of Suspended } \\
\text { Organic Impurity removed }\end{array}$ \\
\cline { 2 - 3 } $\begin{array}{c}\text { Organic Carbon } \\
28 \cdot 4\end{array}$ & $\begin{array}{c}\text { Organic Nitrogen } \\
36 \cdot 6\end{array}$ & \\
$\begin{array}{c}\text { Chemical processes } \\
\text { Intermittent down- }\end{array}$ & & & $89 \cdot 8$ \\
$\quad$ ward filtration - & $72 \cdot 8$ & $87 \cdot 6$ & \\
Irrigation & $-68 \cdot 6$ & $81 \cdot 7$ & $100 \cdot$ \\
& & & $97 \cdot 7$
\end{tabular}

The systems that have been thus briefly referred to are, no doubt, familiar to many, but the comparatively new systems of sewage treatment that I am desirous of bringing before this Section of the Royal Academy of Medicine are yet not very generally known, and in view of the fact that large and costly works are about to be carried out for the sanitary well-being of the City of Dublin, a short reference to each may thus be opportune. By way of preface it is, perhaps, worth noting that in connection with the London Metropolitan sewage disposal problem a combination of lime and proto-sulphate of iron was recommended by Mr. Dibdin, F.C.S., F.I.C., in the proportion of 3.7 grains of lime, in solution, to 1 grain of proto-sulphate of iron per 
gallon of sewage matter. The Metropolitan Board submitted the initiative results of this process to four independent chemists of the highest standing-viz., Sir Frederick Abel, Dr. W. Odling, Dr. A. W. Williamson, and Dr. A. Dupré, who advised that the method of precipitation was a good one, but that it left a sufficiently unpleasant smell to prohibit the effluent water being discharged into the river during warm weather at all states of the tide; and they subsequently recommended, after careful observation of the experiments, that if the liquid, resulting from precipitation with lime and proto-sulphate of iron, was subsequently treated with manganate of soda and sulphuric acid, it would be deodorised and purified to such an extent as to render its discharge into the river Thames unobjectionable at all states of the tide-the resulting sludge being conveyed into deep sea by specially-designed steam barges. My object in making this reference is that in the proposed Main Drainage Scheme for Dublin a similar treatment of precipitation, and carriage to sea, of our metropolitan sewage will be carried out from the plans of Mr. Chatterton, C.E. I am not aware what the precipitant agent is likely to be, but the probability is that the London system may be followed in Dublin in its entirety, and, if such be the case, a final and successful solution to what has been the eye-sore of a century or more will be achieved.

\section{THE INTERNATIONAL SYSTEM,}

or the Ferozone Polarite System of Purification is of very recent date, and where it has been in operation appears to have been most satisfactory, and its results have been very encouraging. It is quite a new departure in sewage treatment, and has excited a considerable deal of interest. It has been in use at Acton for the past four years, and the official reports credit it with being as perfect a system, 


\section{Some Modern Methods of Sewage Treatment.}

if not the most perfect, of sewage purification as has yet been devised, the purified effluent being inodorous, nonputrescible, clear, and tasteless, which can be discharged into a river or water-course without any danger. or any tendency to undergo secondary decomposition. 'The process is carried on in two stages, viz. :-

1. By precipitating and deodorising the sewage in settling tanks by the aid of a magnetic precipitant and deodorant called ferozone.

2. By passing the partly purified sewage effluent from the settling tanks through polarite filter-beds, which arrest any solids remaining in suspension. and oxidise and render innocuous the putrescible matter held in solution.

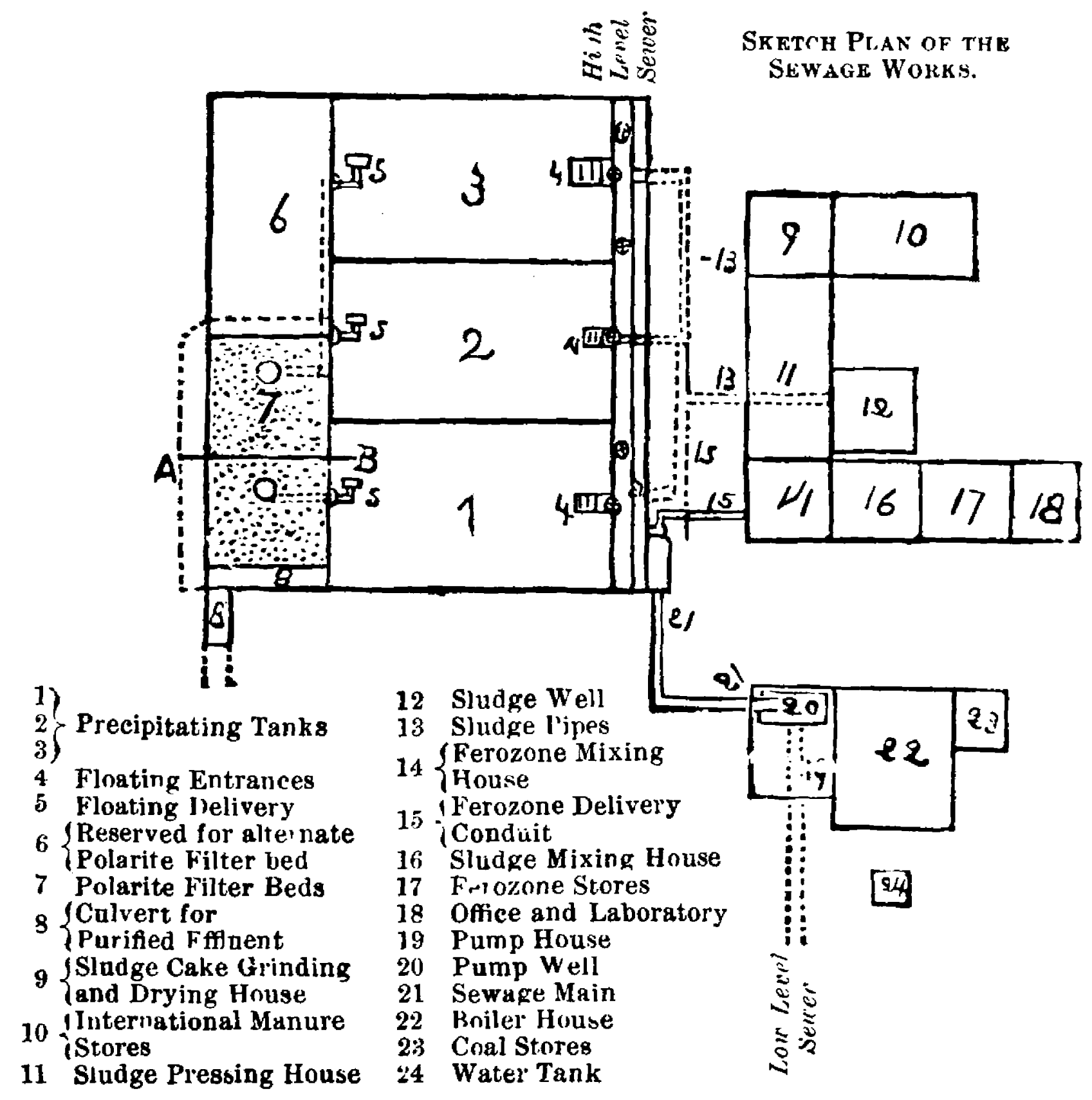

Sketch Plan of the acton Sewage Works, and Section of the Polarite Filter Bed 8. 
Ferozone is the registered trade name of the material used in deodorising sewage, and precipitating the solids therefrom. It is rich in salts of iron, alumina. and magnesia, and also contains magnetic oxide of iron, in a very spongy and absorbent condition; by virtue of its soluble iron and magnesia salts it quickly causes subsidence of the suspended solids.

Polarite is the registered name of the material used for further filtering and purifying the ferozone sewage water from the putrescible matter dissolved therein; it is a black, porous, and magnetic oxide of iron, insoluble in water, and practically everlasting; it is very hard and absorbent; although consisting chiefly of iron, it does not rust, and its durability is unlimited; a cubic yard of polarite weighs about one ton, and is sufficient for rather more than six square yards of filter-bed; moreover, it is cheap enough to bring it into general use.

In carrying out the process of purification by this system, the sewage on reaching the outfall works is run through strainers to arrest floating solids, such as corks, rags, \&c., and then flows quickly through a floating trough into a settling tank, the floor of which inclines towards the centre, so that a gutter may convey the sludge to the outlet valve. Before entering the tank the crude sewage receives a dose of ferozone which costs about one farthing for every thousand gallons of sewage treated. This can be added automatically by placing baskets of ferozone in the flowing sewage or by using Beloe's patent automatic sewage-mixing machine.

In places where the sewage does not How by gravitation, but has to be pumped, and steam-power is therefore available, the ferozone may be ground with water or sewage in a small edge-runner mill and added automatically to the crude sewage in a liquid state. The flow of sewage through the tanks should not be continuous if it can be avoided. 


\section{Some Modem Methods of Servage 'Treatment.}

Quiescent tanks are better for precipitation purposes, whaterer kind of precipitant be used.

When a tank is full its contents should be left standing for about two hours, so that the ferozone may have time to act thoroughly. As towns differ in the quality of their sewage, the needful period of quiescence may vary in different places. The ferozone will cause deodorisation and precipitation to take place in the sewage, and a considerable part of the albuminoids in solution will coagulate and be precipitated with the solids. The supernatant sewage-water thus clarified would then be drawn off and run through polarite filter-beds which produce a higher degree of purification.

The polarite filter-beds usually consist of six inches of broken stone in which small agricultural drain-tiles are embedded, three inches of gravel, six inches of sand, twelve

Section on Line A.B. of Polarite Fibter Brd.

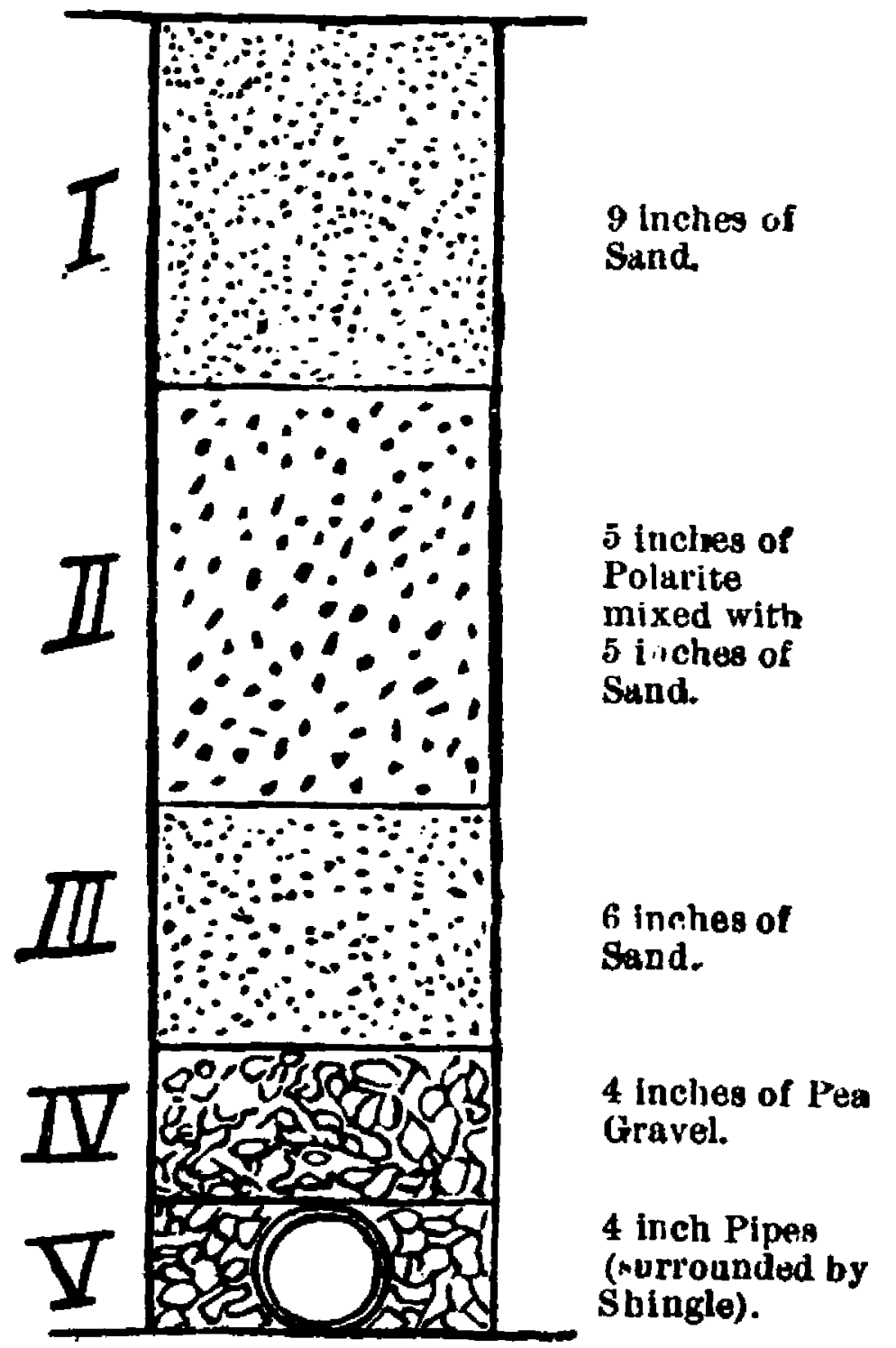

Vertioal Segtion of "Polagite" Filteb Beo. 
inches of polarite and sand mixed in equal proportions, and at the top a layer of nine inches of fine sand, making a total depth of three feet of filtering material. The depth of the layers is sometimes varied to meet special requirements. Polarite filters purify tank effuents which have been treated with ferozone at the rate of 1,000 gallons per square yard in 24 hours. They give better results than are generally produced by land filtration, and at less cost and without nuisance.

Land filters about $1 \frac{1}{2}$ gallons per square yard in 24 hours, therefore one acre of polarite filter-bed will do more effective work than 666 acres of land. Hence the cost is much less than that of a sewage farm, and at the same time the results produced are more certain. The value of polarite for sanitary purposes can scarcely be over-estimated. By using it in small but powerfully active filterbeds it is unnecessary to buy large areas of land for sewage farms which often become a public nuisance.

Land is unable to take a continuous supply of sewage without great deterioration in its purifying and aërating properties. It gets clogged and choked with albuminous and glutinous matters, and becomes sewage-sick and inefficient as a purifying agent. Sewage comes every day to be treated whether the farm is, or is not, in a condition to deal with it. In wet seasons, when the farm is sodden by rain and wants rest, an increased quantity of sewage comes to be purified.

'The polarite filter-bed only requires a fêw hours' rest occasionally for aëration and for cleansing the surface sand, which can be done by an improved method at a nominal cost. The polarite never requires to be removed or replaced. Hence it is better to lay down several small beds rather than one or two large ones, so that they may rest a few hours alternately for aëration and cleansing. 
The resulting ferozone sludge is comparatively inoffensive in odour, and in this regard has an advantage over the lime, and other processes; it has been proved to be richer in manurial value, and the sewage manure produced by the process is shown by analysis to contain nitrogen equal to from one to two per cent. of ammonia, besides phosphates; if placed under cover it dries very quickly, and can be ground into powder. At Acton it is seld as a fine powder at the large sum of $30 \mathrm{~s}$. per ton, whereas in districts where lime is the precipitant the resulting sludge is carted away as a worthless material. Certainly this system of sewage treatment bids fair to solve a difficult problem, and if the resulting sludge can be made to return a fair revenue, I apprehend that urban and rural sanitary authorities will not be slow to recognise its merits. In Ireland it has not had a trial, but it is in operation at Hendon, Swinton, near Manchester, Balmoral, aud sewage works are in process of construction at Guildford, Birkdale, and Sale.

As a filtering medium, polarite appears to have undoubted advantages as compared with sand-filtering material, and it is recommended for filter-beds in water-works, on the ground of economy as well as efficiency. It is well known that sand filter-beds have no chemical purifying power; they merely act as strainers, and retain putrescible matter, instead of oxidising and making them imnocuous, and they leave them unchanged to contaminate the water. An instance of this occurred in the north of England, where an outbreak of typhoid fever was caused by the impurity of the filter-beds at the water-works. A Government inquiry traced the outbreak to fever germs in the filterbeds, and the epidemic did not cease until the filter-beds were closed. Polarite not only enters into the purification of sewage effluents, but is now being used in the laying 
down of filter-beds in various parts of England, and report speaks highly of it as a filtering medium.

\section{THE TREATMENT OF SEWAGE BY ELECTRICITY}

is the most recent of all methods, and may be said to be very promising. Mr. Santo Crimp, referring to the Webster electrical process for sewage purification, says: "When it is considered that the application of electricity is almost daily extended to new objects, and that the science is as yet in its infancy, it must be admitted that the results achieved by the Webster process are of the most encouraging nature. The time may come when our towns will be lighted with electricity by night, whilst by day the dynamos will be employed in purifying the sewage; then the loading of the sewage with chemicals, with the consequent production of large masses of sludge, will no longer be necessary." Sir Henry Roscoe, M.P., F.R.S., has carefully investigated this process, and he mentions that " the quantity of sewage operated on in each experiment was about 20,000 gallons. The reduction of organic matter in solution is the crucial test of the value of a precipitating agent, for unless the organic matter is reduced the effluent will putrefy and rapidly become offensive. I have not observed in any of the unfiltered effluents from this process, which $I$ have examined, any signs of putrefaction, but on the contrary a tendency to oxidise. The absence of sulphuretted hydrogen in samples of unfiltered effluents, which have been kept in stoppered bottles for three weeks, is also a fact of importance. By this process the soluble organic matter is reduced to a condition favourable to the further precipitation by natural agencies." Mr. Alfred Fletcher, F.C.S., F.I.C., Inspector under the Rivers Pollution Prevention Act, states :- " The result of my examination of this process has been to convince me of its efficiency in clarifying sewage, 


\section{Some Modern Methods of Sewage Treatment.}

of removing smell, and in preventing putrefaction of the effluent. I am of opinion that such effluent as I saw at Crossness can be discharged into a river, or after passing through a thin layer of sand, even into a stream, without causing any nuisance."

Analyses of Samples of Seuage treated by Webster's Electrical Process.

Parts Per 19,0,000.

\begin{tabular}{|c|c|c|c|c|c|c|}
\hline Deseription of Sample & 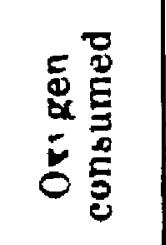 & 窟 & 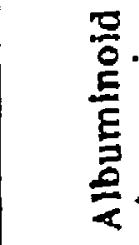 & هُ & 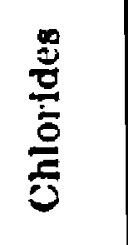 & Notes \\
\hline $\begin{array}{l}\text { (A) Mixture of } 3 \text { samples of } \\
\text { raw sewage collected aur. } \\
\text { ing time of treatment }\end{array}$ & $2 \cdot 292$ & $1 \cdot 9$ & $0 \cdot 65$ & & $44 \cdot 4$ & $\begin{array}{l}\text { Strnk badly on 3rd } \\
\text { day }\end{array}$ \\
\hline $\begin{array}{l}\text { (B) Mixture of } 3 \text { samples of } \\
\text { treated sewage flowing } \\
\text { into tank before settling }\end{array}$ & 0.917 & $1 \cdot 75$ & 0.6 & & $37 \cdot 2$ & $\begin{array}{l}\text { Faint smell on 5th } \\
\text { day }\end{array}$ \\
\hline $\begin{array}{l}\text { (C) Same as sample } A \text { after } \\
\text { settling } 24 \text { hours }\end{array}$ & - & $1 \cdot 64$ & 0.4 & & - & $\begin{array}{l}\text { Stank badly on } 3 r d \\
\text { day }\end{array}$ \\
\hline $\begin{array}{l}\text { (D) Same as sample } B \text { after } \\
\text { settling } 24 \text { hours }\end{array}$ & - & 1.84 & $0 \cdot 12$ & & - & $\begin{array}{l}\text { Faint smell on 5th } \\
\text { day }\end{array}$ \\
\hline $\begin{array}{l}\text { No. 7. Average sample of } \\
\text { raw sewage under treat- } \\
\text { ment }\end{array}$ & $2 \cdot 5$ & 1.8 & 0.65 & & $41 \cdot 2$ & $\begin{array}{l}\text { Stank badly on 3rd } \\
\text { day }\end{array}$ \\
\hline $\begin{array}{l}\text { No. 8. Treated sewage after } \\
2 \text { hours' settlement in } \\
\text { tank }\end{array}$ & 0.583 & $1 \cdot 08$ & 0.07 & & $35 \cdot 8$ & $\begin{array}{l}\text { Perfectly sweet aftel } \\
10 \text { days }\end{array}$ \\
\hline $\begin{array}{l}\text { No. 9. Same as No. } 8 \text { after } \\
\text { filtration through } 6 \text { in. of } \\
\text { sand }\end{array}$ & 0.536 & 1.00 & 0.06 & 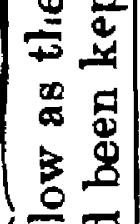 & $35 \cdot 6$ & ditto \\
\hline $\begin{array}{l}\text { No. 10. Treated sewage after } \\
\text { 3it hours' settlement in } \\
\text { tank }\end{array}$ & 0.5 & $1 \cdot 28$ & 0.05 & 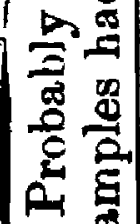 & $35 \cdot 6$ & ditto \\
\hline $\begin{array}{l}\text { No. 11. Same as No. } 10 \text { after } \\
\text { fliration through } 6 \text { in. } \\
\text { of sand }\end{array}$ & $0 \cdot 5$ & 0.91 & $0 * 01$ & & $35 \cdot 6$ & ditto \\
\hline
\end{tabular}

The effluent produced by the electrical process, Mr. Webster states, contains about three grains per gallon 
of suspended matters, which consist almost entirely of oxide of iron, which is quite innocuous. Where this may be objectionable, from a sentimental point of view, it can be entirely removed by filtration through a few inches of sand.

The bacteria question is one which has probably still to be settled, but, in order to obtain some information as to the action of the iron compound produced by electrochemical decomposition, some experiments were carried out, with the result that, after a given treatment, the whole of the bacteria were killed. In the case of experiments carried out in Paris, with ordinary treatment by means of iron electrodes, the results were as follows:-

$$
\begin{array}{ccc}
\text { Organisms per cubic centimetre, } & \begin{array}{c}
\text { Raw Sewage } \\
\overline{5}, 000,000
\end{array} & \text { Effluent } \\
600
\end{array}
$$

In another experiment, in which the effluent was treated still further, all organisms were destroyed.

Unquestionably this process of sewage treatment has many advantages, and may yet solve the vexed sewage problem.

Mr. Webster remarks further, " That it was while working with perchloride of iron, as a purifier of sewage, that the importance of iron salts, in relation to organic matter, became apparent; and it was in connection with this chemical and free chlorine gas that the idea of electrolysis suggested itself."

\section{THE " OXYGEN PROCESS."}

A new process, which has had its birth in Ireland, and which promises to fully realize the expectation of its promoters, is the "Oxygen Process of Sewage Purification," devised by Mr. W. E. Adeney, F.I.C., and Mr. W. Kaye Parry, M.A., C.E. It has been submitted to an exhaustive investigation both in the laboratory and at some works at Monkstown, and the results have been successful. The pro- 
cess, moreover, has been examined in detail by the Chief Surveyor to the Board of Public Works, and has been selected by that body for the purification of the sewage of the Lunatic Asylum at Dundrum. To be brief, the results effected by this process are the complete separation of all matters in suspension in sewage, in a state suitable for air drying and utilisation as a manure, and an effluent of any degree of purity according to the circumstances of the locality to which it is applied may demand, one of the most interesting features in the process being the separation of the solids, uithout the addition of precipitating chenicals.

In this process the solid matters in the sewage are first separated from the soluble constituents by subsidence in a tank of special construction, no precipitating chemicals being employed. The destruction of the fermentable organic matters in solution in ordinary sewage is effected by taking advantage of the power which harmless micro-organisms, the germs of which are known to be widely distributed in the earth, air, and water, have, when growing under the most favourable conditions, of rapidly decomposing such matters into carbonic acid, water, ammonia, and also nitric acid. Under proper conditions these products result directly from the decomposition of the soluble fermentable matters in sewage, without any intermediate putrefactive fermentation being set up. The formation of offensive bodies is, in fact, entirely avoided in this process.

The essential condition for the healthy and rapid action of the organisms here referred to, is a plentiful supply of oxygen, free or combined. The necessary supply of oxygen is secured by a careful use of nitrate and manganate of sodium. One of the products of decomposition of the latter chemical is oxyhydrate of manganese; it is completely recovered by subsidence in a second tank, similar in construction to the one employed for the separation of the 
solid matters of the sewage. The recovered oxyhydrate of manganese may be dried and re-converted into manganate of sodium, and so may be used over and over again. It may also be employed for mixing with the solid matters of the sewage separated in the first tank to prevent putrefactive fermentation being set up in them during the process of air-drying them.

Another system,

\section{THE SHONE HYDRO-PNEUMATIC SYSTEM,}

is also of comparatively recent date, and is in operation at Eastbourne, Shirley, and Freemantle, near Southampton, Lowestoft, Stoke-on-Trent, and some other thirty or forty towns in England, as well as at the Houses of Parliament. The system appears to work admirably, and is particularly adapted to districts and towns of a low-lying nature, and where the volume of sewage is insufficient to cause what is termed a self-cleansing velocity in the sewers. Correctly speaking, the Shone System might be better described as a successful method of getting rid of sewage by means of automatic sewage ejectors, and a writer described it some time since in the columns of The Health Record as a system so elastic in its application that it can not only be successfully applied to a solitary building, but is equally adaptable to towns, cities, and rural districts.

In the subjoined illustration, the working of the Automatic Sewage Ejectors is shown, and is carried out as follows:-

The sewage gravitates from the sewers through the Inlet Pipe $\mathrm{A}$ into the Ejector, and gradually rises therein, until it reaches the underside of the bell $D$. The air at atmospheric pressure inside the bell is then enclosed, and the sewage continuing to rise outside and above the rim of the bell compresses the enclosed air sufficiently to lift the 


\section{Some Modern Methods of Sewage Treatment.}

bell, spindle, \&c., which opens the Compressed Air Admission Valve E. The compressed air thus automatically admitted into the Ejector presses on the surface of the sewage, driving the whole of the contents before it through the bell-mouthed opening at the bottom, and through the Outlet Pipe $B$ into the iron sewage rising main or high level gravitating sewer, as the case may be. The sewage can only escape from the Ejector by the outlet pipe, as the instant the air pressure is admitted on to the surface of the fluid the valve on the Inlet Pipe A falls on its seat and

Automatic Sewage Ejector.

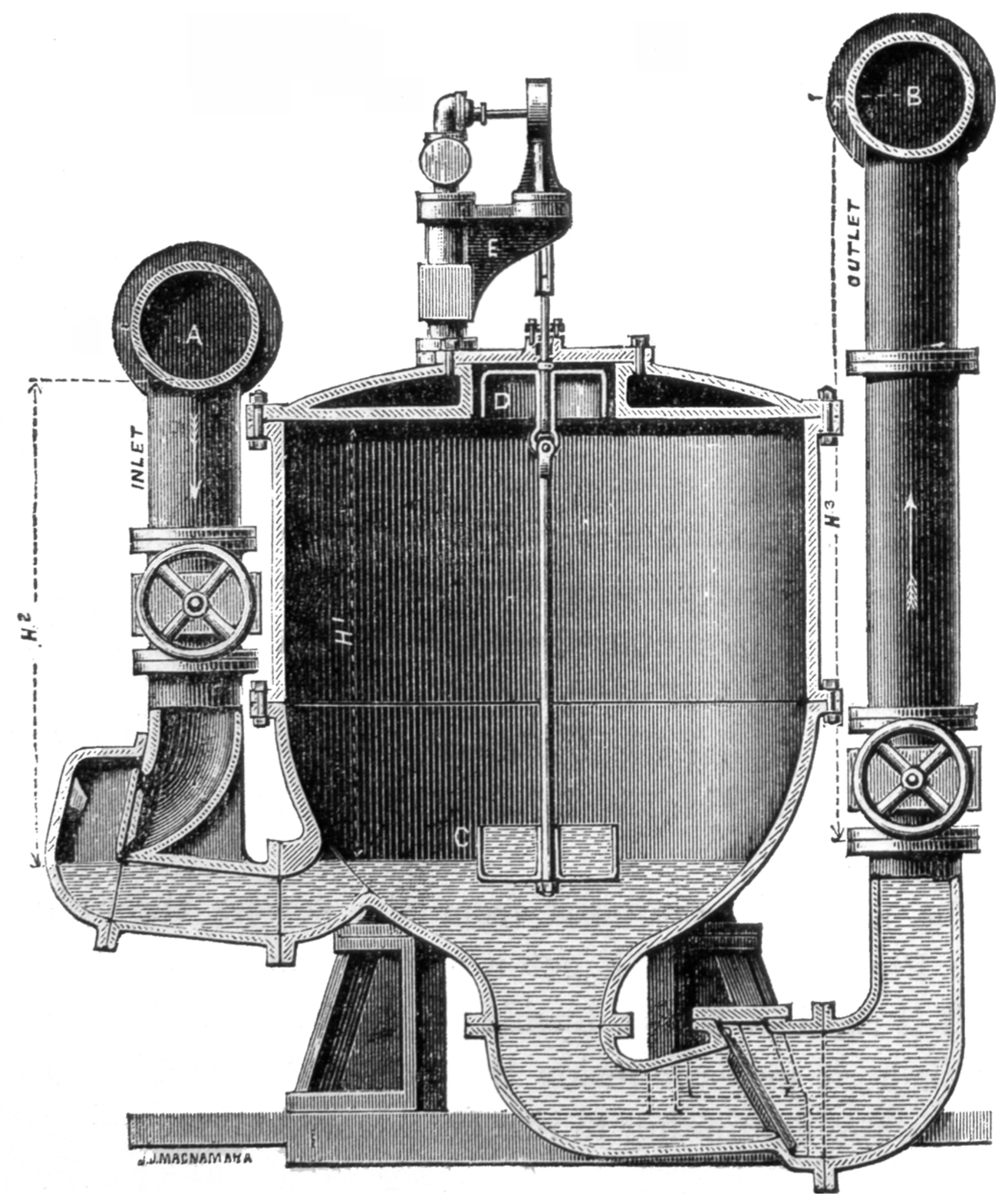


prevents the fluid escaping in that direction. The fluid passes out of the Ejector until its level therein reaches the cup C, and still continuing to lower, leaves the cup full until the weight of the liquid in the portion of the eup thus exposed and unsupported by the surrounding water is sufficient to pull down the bell and spindle, thereby reversing the Compressed Air Admission Valve, which first cuts off the supply of compressed air to the Ejector, and then allows the air within the Ejector to exhaust down to atmospheric pressure. The outlet valve then falls on its seat retaining the liquid in the sewage rising main; the sewage then flows into the Ejector through the inlet once more, driving the free air before it through the air valve, as the sewage rises, and so the action goes on as long as there is sewage to flow.

The valuable feature connected with the system consists in this-that by its aid the "separate system" of drainage can be carried out in the most perfect and sanitary manner possible, whether the district to be drained be flat, low-lying, tide-locked, or otherwise. All the chief sanitary engineers of the present day recommend the adoption of the separate system in preference to the combined system. But towns drained on the separate system now are few and far between, the reason being that the engineers who have designed the works could never get the hydraulic conditions necessary to cause the sewage to flow freely to what are called the outfalls; because it is well known that small volumes of sewage require to be turned into small sewers, having inclinations suitable to their sizes; and in flat districts the necessary inclinations can never be obtained.

In those districts hitherto drained by gravitation per se, the practice has been to constract big sewers at such gradients or inclinations as the configuration of the country or town would admit of. In dry weather, when only the 


\section{Some Modern Methods of Sewage Treatment.}

sewage proper is discharged into such sewers, the volume is insufficient to cause what are called a self-cleansing velocity in the sewers, which then become sewers of deposit, and the large spaces within them not occupied by the sewage are more or less filled with foul air mixed with sewage gases, and these are permitted to escape haphazard into the streets under which they are laid, and into the houses with which they are connected.

In this manner unsanitary, and not sanitary, drainage works have been, and still are being, executed all over the world. But by the Shone System the most perfect hydraulic gradients can be secured throughout the whole area to be drained. Besides securing self-cleansing sewers by the Shonte System, these sewers can be effectually ventilated by the action of the ejectors in a most simple but thoroughly scientific and practical manner.

It will be noted that the modern or later attempts to solve the sewage difficulty possess many features of practical interest, and I claim the indulgence of this Section if I have unduly trespassed on its time.

Professor Charles Tichborne said that Mr. Flinn's paper' was of great interest, because it brought before them the various processes which had lately been tried for sewage treatment. The great difficulty of all methods of sewage disposal was that this difficulty grew directly as the size of the town they had to deal with. Therefore every town required its special treatment, and he did not believe that any universal system was applicable. Some years ago he, the speaker, had been taken by Mr. Dibdin, Chemist to the Metropolitan Board, to see the method adopted at London. 'The process at that time was a very simple one. It consisted in carrying down the sewage by two main sewers into settling tanks, pumping the effluent into the river, and taking away the sludge by steam barges and emptying it into the sea. He was told that evell at that time the great difficulty they had to contend with was to dispose of the sedimentary sludge quick enough. How much 
greater would that be with the monster city where they were using precipitants. The effluent presented no difficulty. A small proportion of manganate of sodium was added before pumping for the purpose of destroying effluvia. The interesting process mentioned by Mr. Flinn, in which magnetic oxide of iron played so important a part, seemed to Prof. Tichborne to be based on a similar theory to the porous iron filters which had been found so successful. There was nothing new about the use of manganates and permanganates for sewage purification. He should like to hear how far the irrigation system was carried out at Birmingham. Birmingham was a very large town, and if $\mathrm{Mr}$. Flinn could tell them something about that, it would be very interesting.

Dr. Alfred Paksons regretted that Mr. Fliun had devoted such a large part of his paper to an account of the chemistry of the methods of sewage trextment, while the bacteriological aspect of the question had been dismissed in a few brief sentences. 'To him the latter seemed to be the all-important side of the subject. He yielded to none in his respect for the science of chemistry. It had had a glorious record in the past, and there was a brilliant future before it, but he maintained that the value of any method of sewage treatment must be weighed in the balance of bacteriology and not of chemistry. Numerous opinions of distinguished chemists, from Sir Henry Roscoe to Professor Adeney, had been laid before them, and the most they appeared able to say of any system was that the effluent was colourless, tasteless, odourless, but a fluid, he believed, might possess these characters and yet contain large numbers of typhoid bacilli. A liquid, swarming with pathogenic organisms, which from its odour, taste, and appearance is repulsive, is likely to do less injury than a fluid containing similar organisms, but commendable from fulfilling those criteria on which the chemists appear to lay so much stress. Till an exhaustive bacteriological examination of the fluid after precipitation has been made, he must look with great suspicion on any method of treatment in which the effluent is poured into superficial drains which in their course may contaminate many sources of water supply. The use of the sludge for manuring vegetables appeared to him likewise to be fraught with danger, and it did not seem to him to require any vivid imagination-in the absence of any information in the paper of the bactericidal properties of the substance used in the process of precipitation - to understand how typhoid fever might be propagnted by the minute particles adhering to imperfectly washed, unconkod 


\section{Some Modern Methods of Seurage Treatment.}

vegetables such as lettuce, assuming the presence of typhoirl dejecta in the original sewage matter.

Dr. Chartes Moore asked Mr. Flinn what was the "Shone System," and if it could be carried out in detail without forming the great aggregate of sewage now so generally the result of inain drainuge systems. The great difficulty of such systems beingr the vast amount of liquid matter that has to be dealt with. The prevention of contamiuation of sewers by the matter from the 80 slaughter yards about Dublin and from other well-known sources of contamination should be insisted upon. The pumping of the surface water by the old pumps of Dublin was an important measure of prevention of many diseases-as phthisis, \&c. The larger the system of main drainage the less surface drainage pumping by steam works.

Dr. MacDowel Cosgrave asked for the comparative expen-e of the Shone process.

Mr. FlinN replied. 